\footnotetext{
JURNAL CEMERLANG: Pengabdian pada Masyarakat

P-ISSN 2654-4741 / E-ISSN 2655-7894

Vol. 2, No. 1, Desember 2019, 24 - 33

DOI: https://doi.org/10.31540/jpm.v2i1.636

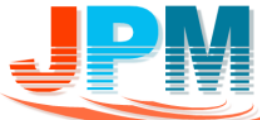

PENERBIT: LP4MK STKIP PGRI LUBUKLINGGAU
}

\title{
SOSIALISASI STRECHING DINAMIS BOLA BASKET BERSAMA PERSATUAN BOLA BASKET SELURUH INDONESIA KABUPATEN BANGKALAN DI SEKOLAH DASAR NEGERI KERATON 3
}

\author{
Heni Yuli Handayani \\ STKIP PGRI Bangkalan, Indonesia \\ Email: heni@stkippgri-bkl.ac.id
}

\begin{abstract}
ABSTRAK
Kegiatan pengabdian kepada masyarakat ini merupakan kegiatan sosialisasi bekerjasama dengan PERBASI Kabupaten Bangkalan yang diharapkan dapat memberikan kontribusi dalam peningkatan kualitas proses pembelajaran khususnya dalam mata pelajaran olahraga. Dengan adanya sosialisasi streching dinamis dalam permainan bola basket di rasa tepat sebagai hal yang bermanfaat dan memberikan kontribusi kepada sekolah mitra khususnya SD Negeri Keraton 3 Bangkalan. Adapun hasil dari kegiatan pengabdian masyarakat ini adalah adanya peningkatan pemahaman baru yang berorientasi kepada pemahaman tentang pelaksanaan pemanasan (streching) dinamis pada siswa sekolah dasar sebelum melakukan olahraga, peningkatan kemampuan siswa dalam permainan kecil bola basket yaitu line tiggy, Dribble Knockout, Team Dribble Relays (Speed Dribble \& Ball Handling), 4 Pass to Score, Bull in the ring. Berdasarkan hasil tersebut dapat ditarik kesimpulan bahwa sosialisasi streching dinamis dalam permainan bola basket bagi siswa SD dinilai baik dan efektif, dan respon siswa selama mengikuti kegiatan memberikan respon yang positif.
\end{abstract}

ABSTRACT

This community service activity is a socialization activity in collaboration with PERBASI Bangkalan Regency which is expected to contribute to improving the quality of the learning process, especially in sports subjects. With the dynamic streching socialization in the basketball game, it is felt appropriate as a useful thing and contributing to partner schools especially SD Negeri Keraton 3 Bangkalan. As for the results of this community service activity is an increase in new understanding oriented to the understanding of the implementation of dynamic warming (streching) in elementary school students before doing sports, increasing student ability in small basketball games namely line tiggy, Dribble Knockout, Team Dribble Relays (Team Dribble Relays ( Speed Dribble \& Ball Handling), 4 Pass to Score, Bull in the ring. Based on these results it can be concluded that the socialization of dynamic streching in basketball games for elementary students is considered good and effective, and the students' responses during the activity give a positive response.

KEYWORDS

Streching Dinamis, Bola Basket, Olahraga

Dynamic Streching, Basketball, Sports
ARTICLE HISTORY

Received 11 November 2019

Revised 29 November 2019

Accepted 12 December 2019

CORRESPONDENCE Heni Yuli Handayani @ heni@stkippgri-bkl.ac.id 


\section{JURNAL CEMERLANG: Pengabdian pada Masyarakat \\ P-ISSN 2654-4741 / E-ISSN 2655-7894 \\ Vol. 2, No. 1, Desember 2019, 24 - 33 \\ DOI: https://doi.org/10.31540/jpm.v2i1.636 \\ PENERBIT: LP4MK STKIP PGRI LUBUKLINGGAU}

\section{PENDAHULUAN}

Pendidikan jasmani pada dasarnya merupakan pendidikan melalui aktivitas jasmani yang dijadikan sebagai media untuk mencapai perkembangan individu secara menyeluruh. Melalui pendidikan jasmani, siswa disosialisasikan ke dalam aktivitas jasmani termasuk keterampilan berolahraga. Pendidikan jasmani merupakan usaha pendidikan dengan menggunakan aktivitas otot-otot besar sehingga proses pendidikan yang berlangsung tidak terhambat oleh gangguan kesehatan dan pertumbuhan badan. Sebagai bagian integral dari proses pendidikan keseluruhan, pendidikan jasmani merupakan usaha yang bertujuan mengembangkan kawasan organik, neuromaskul intelektual, dan sosial (Adang Suherman, 2000:15).

Aktifitas jasmani dapat berjalan dengan baik sesuai dengan tujuannya apabila tidak terlepas dari peran serta semua pihak yang terkait baik pihak sekolah dan masyarakat sekitar karena dengan adanya dukungan dari berbagai pihak maka akan tercapai tujuan yang diinginkan. Selain peran pihak-pihak tertentu, kondisi lingkungan sekolah dan kreatifitas seorang guru dalam proses mengajar sangat perlu sehingga dapat menunjang keberhasilan proses belajar mengajar (Lutan. 1997:27). Banyak hal yang dapat dilakukan seorang guru untuk mengembangkan kreatifitasnya salah satunya dengan memodifikasi bentuk permainan ke dalamsuatu pembelajaran. Modifikasi adalah menganalisa dan mengembangkan materi pelajaran dengan cara meruntunkannya dalam bentuk aktivitas belajar potensial yang dapat memperlancar siswa dalam belajarnya (Mahendra, 2009:29).

Pendidikan jasmani di tingkat Sekolah Dasar sangat mempengaruhi pertumbuhan dan perkembangan peserta didik. Rangsangan utama bagi pertumbuhan dan perkembangan anak adalah gerak, semakin banyak bergerak maka anak akan semakin banyak belajar serta mengetahui banyak hal (Tedjasaputra, 2001:29). Karakteristik anak di tingkat Sekolah Dasar yaitu suka bermain, melalui bermain anak akan merasa senang dan melakukan banyak gerak (Al-khalili. 2005:46). Bergerak tidak hanya merupakan kebutuhan alami peserta 


\section{JURNAL CEMERLANG: Pengabdian pada Masyarakat \\ P-ISSN 2654-4741 / E-ISSN 2655-7894 \\ Vol. 2, No. 1, Desember 2019, 24 - 33 \\ DOI: https://doi.org/10.31540/jpm.v2i1.636 \\ PENERBIT: LP4MK STKIP PGRI LUBUKLINGGAU}

didik Sekolah Dasar, melainkan juga membentuk, membina, dan mengembangkan anak, serta meningkatkan intelektual anak didik (Suherman, 2009). Pendidikan Jasmani dan Kesehatan disekolah salah satunya yaitu dengan diberikannya materi pembelajaran tentang cabang olahraga bola basket.

Bola basket adalah olahraga bola berkelompok yang terdiri atas dua tim beranggotakan masing-masing lima orang yang saling bertanding mencetak poin dengan memasukkan bola ke dalam keranjang lawan (Ahmadil. 2007:12). Terdapat beberapa gerakan yang dipergunakan dalam permainan bola basket seperti: passing (melempar bola), dribling (menggiring), shooting (menembak), ball handling (penguasaan bola), rebounding (memantulkan bola), intercept (memotong arah passingbola), steals (merebut bola), dan foot work (pergerakan kaki) (Ano, 2010:52). Dari beberapa gerakan yang telah diuraikan, shooting adalah salah satu gerak dasar dalam permainan bola basket yang dipelajari oleh siswa sekolah dasar (SD).

Permainan bola basket dikenal sebagai olahraga yang dinamis dan aktraktif, karena menuntut suatu kombinasi kemampuan fisik dan keterampilan teknik yang berkualitas. Dilihat dari karakteristik permainan bola basket merupakan jenis olahraga yang banyak menuntut para atletnya menguasai teknik dan memiliki kondisi fisik yang baik tanpa mengabaikan aspek taktik dan mental. Mengenai hal ini (Sanoesi 2012: 40) mengemukakan bahwa: "Ada empat aspek latihan yang perlu di perhatikan dan dilatih secara seksama oleh atlet, yaitu: latihan fisik, latihan teknik, latihan taktik dan latihan mental."

Secara garis besar permainan Bola Basket dilakukan dengan mempergunakan beberapa unsur teknik yang menjadi pokok permainan, sebagaimana yang dijelaskan oleh Ambler dalam Wissel (2000:12). Keterampilan dasar dalam permainan bola basket yaitu meliputi beberapa keterampilan berikut ini: penguasaan bola (ball handlling), menangkap bola (catching), mengoper bola (passing), menembakan bola (shooting), menggiring bola (dribling) (Sumiharyono, 2002:22). Sampai sekarang PERBASI yang bertanggung jawab 


\section{JURNAL CEMERLANG: Pengabdian pada Masyarakat \\ P-ISSN 2654-4741 / E-ISSN 2655-7894 \\ Vol. 2, No. 1, Desember 2019, 24 - 33 \\ DOI: https://doi.org/10.31540/jpm.v2i1.636 \\ PENERBIT: LP4MK STKIP PGRI LUBUKLINGGAU}

atas perkembangan bolabasket di Indonesia. Perkembangan bolabasket di Indonesia dewasa ini juga berkembang dengan cepat dan pesat, hingga sampai sekarang bolabasket sudah tersebar di seluruh daerah, propinsi dan kabupaten di Indonesia, termasuk salah satunya di Bangkalan khususnya pada SD Negeri Keraton 3.

Kontribusi yang dilakukan oleh PERBASI Kabupaten Bangkalan untuk berpartisipasi dalam memajukan bola basket di Kabupaten Bangkalan patut untuk diapresiasi dengan baik melalui dukungan lingkungan sekitarnya. Salah satu agenda PERBASI di Kabupaten Bangkalan yang pernah dilakukan untuk meningkatkan animo bola basket di kalangan anak usia dini yaitu saat tahun 2010. Meningkatnya gairah masyarakat dalam olahraga bola basket ini juga memberikan inisiatif bagi PERBASI Kabupaten Bangkalan untuk berperan serta pada bola basket di tingkat sekolah dasar dengan memunculkan program bantuan sarana dan pembimbingan latihan. Pada tahun tersebut PERBASI Kabupaten Bangkalan memberikan bantuan tiang, papan, keranjang dan bola basket pada beberapa Sekolah Dasar Negeri di Kecamatan Bangkalan sebagai stimulus untuk ikut mengembangkan olahraga bola basket pada anak usia dini. Kegiatan tersebut berlanjut dengan adanya pendampingan ekstrakurikuler bola basket selama sebulan penuh hingga sekolah tersebut dapat dengan mandiri melanjutkan program yang ada.

Dalam beberapa tahun terakhir program serupa belum dapat dilaksanakan lagi oleh PERBASI Kabupaten Bangkalan. Melalui permainan kecil yang diterapakan dalam permainan bola basket dapat memberikan alternatif untuk dapat memainkan bola basket dengan peraturan dan lapangan yang dimodifikasi. Permainan kecil bola basket yang digunakan walau tidak mengunakan sarana dan peraturan sebenarnya namun minimal dapat mengenalkan bola basket kepada anak usia dini serta melatih beberapa teknik dasar yang dimiliki.

Sosialisasi streching dinamis bola basket bersama persatuan bola basket seluruh indonesia kabupaten bangkalan belum pernah dilakukan sebelumnya 


\section{JURNAL CEMERLANG: Pengabdian pada Masyarakat \\ P-ISSN 2654-4741 / E-ISSN 2655-7894 \\ Vol. 2, No. 1, Desember 2019, 24 - 33 \\ DOI: https://doi.org/10.31540/jpm.v2i1.636 \\ PENERBIT: LP4MK STKIP PGRI LUBUKLINGGAU}

sehingga pemanasan sebelum pelaksanaan permainan bola basket melalui permainan kecil bola basket pada anak usia SD di sekolah dasar diharapkan dapat menjadi uji coba penggunaannya dalam mengatasi permasalahan yang dihadapi oleh PERBASI Kabupaten bangkalan dalam melakukan sosialisasi permainan bola basket.

Pada saat akan memulai suatu aktifitas olahraga, stretching (peregangan) atau lebih dikenal orang dengan istilah pemanasan (warm-up) sangat diperlukan. Stretching adalah bentuk dari penguluran atau peregangan pada otot-otot di setiap anggota badan agar dalam setiap melakukan olahraga terdapat kesiapan serta untuk mengurangi dampak cedera yang sangan rentan terjadi. Stretching atau pereganganan otot adalah aktivitas yang biasanya dilakukan sebelum atau setelah olahraga. Kegiatan ini bertujuan untuk membuat oto dan persendian menjadi fleksibel dan elastic. Sehingga menjadi lebih mudah pada saat melakukan pergerakan. Selain hal tersebut, stretching juga berfungsi menghindari cidera pada saat berolahraga.

\section{METODE}

Metode pelaksanaan pengabdian kepada masyarakat ini dilaksanakan dalam bentuk sosialisasi dan pelatihan, melalui beberapa tahapan sebagai berikut:

\section{Tahapan Perencanaan dan Persiapan}

Tahapan ini merupakan langkah awal sebelum pelaksanaan sosialisasi. Tahapan awal sebelum pelaksanaan sosialisasi ialah melakukan perencanaan kegiatan, selanjutnya melaksanakan survey dan mendiskusikan permasalahan yang dihadapi mitra. Mitra dalam hal ini adalah SD Negeri Keraton 3 Kabupaten Bangkalan Provinsi Jawa Timur. Pada tahapan ini juga melakukan wawancara terhadap beberapa guru olahraga disekolah terkait pandangan mereka terhadap pelaksanaan pembelajaran olahraga terutama streching dinamis dan permainan kecil bola basket. Setelah pihak mitra mendapat gambaran yang utuh tentang 


\section{JURNAL CEMERLANG: Pengabdian pada Masyarakat \\ P-ISSN 2654-4741 / E-ISSN 2655-7894 \\ Vol. 2, No. 1, Desember 2019, 24 - 33 \\ DOI: https://doi.org/10.31540/jpm.v2i1.636 \\ PENERBIT: LP4MK STKIP PGRI LUBUKLINGGAU}

kegiatan yang akan dilaksanakan, selanjutnya melakukan kesepakatan bersama mitra untuk melaksanakan kegiatan yang telah direncanakan.

\section{Tahapan Pelaksanaan Sosialisasi dan Praktik}

Secara teknisnya, lokasi kegiatan pengabdian masyarakat telah di laksanakan selama lima bulan mulai sejak bulan Juli sampai dengan bulan Nopember 2019 di SD Keraton Kabupaten Bangkalan Jawa Timur. Tahap awal dari kegiatan Pengabdian Masyarakat ini adalah presentasi yang telah dijelaskan oleh tim Kegiatan Pengabdian kepada Masyarakat. Tim ini menjelaskan tentang pentingnya pemanasan (Streching) dinamis sebelum melakukan kegiatan olahraga serta penjelasan tentang permainan kecil bola basket bagi siswa sekolah dasar.

Pada tahap kedua, peserta kegiatan yang ada di sekolah mitra juga di ajarkan tahap - tahap dalam pelaksanaan praktik straching dinamis dan olehraga kecil bola basket. Secara garis besar, kegiatan ini berjalan sesuai rencana yang sudah di susun jauh - jauh hari sebelumnya. Hal ini dapat di buktikan dari antusias peserta yang mengikuti kegiatan pengabdian kepada masyarakat ini.

\section{Evaluasi}

Evaluasi kegiatan pengabdian masyarakat dengan metode sosialisasi ini dilakukan untuk mengetahui sejauh mana keberhasilan kegiatan pengabdian yang telah dilaksanakan. Dalam proses tahapan sosialisasi dan praktik, kegiatan PKM ini berjalan dengan baik guru dan siswa dapat memahami tujuan pelaksanaan kegiatan ini secara maksimal. Kesimpulan ini berdasarkan sesi tanggapan dan tanya jawab saat kegiatan berlangsung, meskipun demikian sesuai dengan tujuan masalah PKM ini masih membutuhkan tindak lanjut dalam bentuk mediasi dan konsultasi dengan pihak PERBASI Kabupaten Bangkalan guna untuk memperoleh informasi kemajuan minat siswwa dalam pelaksanaan olahraga kecil bola basket.

\section{HASIL}

Pelaksanaan sosialisasi ini mendapat dukungan penuh dari pihak mitra, yakni sekolah dasar negeri keraton 3 bangkalan dengan memfasilitasi tempat dan 


\section{JURNAL CEMERLANG: Pengabdian pada Masyarakat P-ISSN 2654-4741 / E-ISSN 2655-7894 \\ Vol. 2, No. 1, Desember 2019, 24 - 33 \\ DOI: https://doi.org/10.31540/jpm.v2i1.636

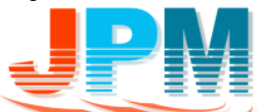 \\ PENERBIT: LP4MK STKIP PGRI LUBUKLINGGAU}

menghadirkan peserta dalam pelaksanaan sosialisasi sebanyak 30 peserta. Sosialisasi pentingnya streching sebelum melakukan olahraga ini adalah untuk memberikan gambaran serta pengetahuan bagi siswa sekolah dasar sebelum olahraga.

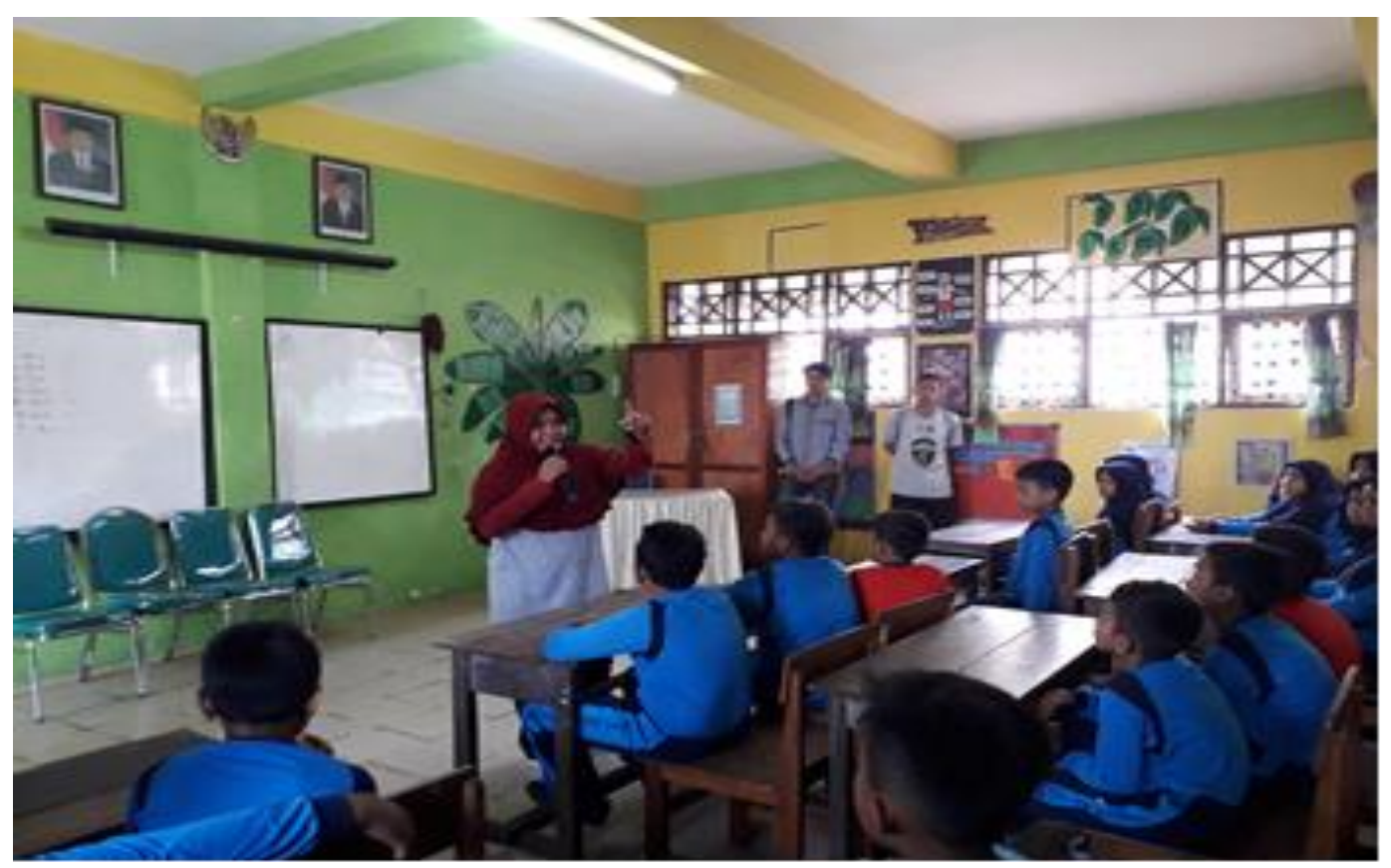

Gambar 1. Sosialisasi materi Stretching

Selama kegiatan sosialisasi berlangsung siswa sekolah dasar sangat antusias mendengarkan materi yang di sampaikan dari pemateri. Siswa pun aktif dan banyak bertanya sehingga suasana menjadi hidup. Dengan kegiatan sosialisasi ini diharapkan siswa-siswi mampu manambah wawasan siswa tentang pentingnya pelaksanaan streching sebelum melakukan olahraga.

Pada tahap kedua peserta kegiatan yang ada di sekolah mitra juga di ajarkan tahap - tahap dalam pelaksanaan praktik streching dinamis. Streching adalah peregangan yang dilakukan dengan bergerak melalui berbagai tantangan, tetapi nyaman untuk digerakkan berulang kali, biasanya hingga 10-12 kali. Meskipun dinamis, peregangan ini memerlukan koordinasi yang lebih tinggi dibandingkan peregangan statis. Peregangan ini sangat digemari oleh atlet, pelatih, instruktur 


\section{JURNAL CEMERLANG: Pengabdian pada Masyarakat P-ISSN 2654-4741 / E-ISSN 2655-7894 \\ Vol. 2, No. 1, Desember 2019, 24 - 33 \\ DOI: https://doi.org/10.31540/jpm.v2i1.636

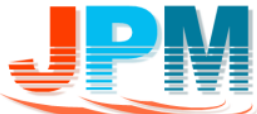 \\ PENERBIT: LP4MK STKIP PGRI LUBUKLINGGAU}

dan terapis fisik karena manfaatnya dalam meningkatkan rentang fungsional gerak dan mobilitas dalam olahraga dan kehidupan sehari-hari.

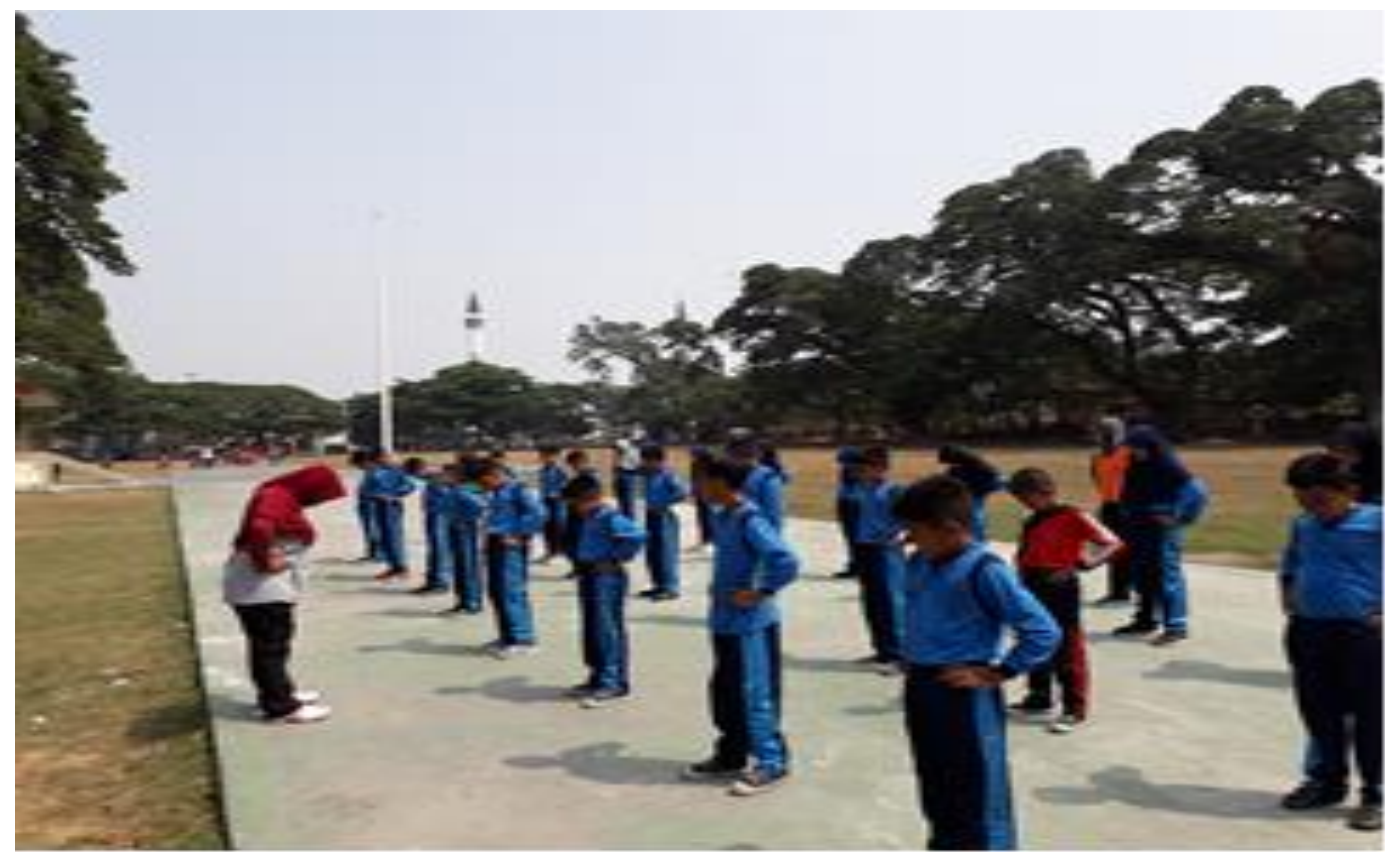

Gambar 1. Praktik Stretching

Stretching atau Peregangan dinamis adalah gerakan peregangan yang dilakukan dengan melibatkan otot-otot dan persendian, gerakan peregangan ini dilakukan secara perlahan dan terkontrol dengan pangkal gerakannya adalah pangkal persendian. Peregangan dinamis, dilakukan dengan melakukan gerakangerakan meregangkan. Dengan tujuan untuk mencapai pergerakan persendian seluas mungkin, melampaui batas kemampuan yang dimiliki.

Gerakan pada latihan peregangan dinamic juga dapat dipakai untuk latihan fleksibilitas atau kelentukan tubuh. Peregangan dinamis biasanya dilakukan dengan menggerak-gerakkan tubuh secara ritmis. Latihan peregangan dinamis dapat dilakukan dengan gerakan-gerakan berirama misalnya memutar atau memantul-mantulkan anggota tubuh sehingga badan terasa teregangkan. Gerakan peregangan bertujuan untuk meningkatkan ruang gerak otot-otot dan sendi-sendi tubuh secara bertahap. Dalam pelaksanaan pengabdian masyarakat ini praktik 


\section{JURNAL CEMERLANG: Pengabdian pada Masyarakat \\ P-ISSN 2654-4741 / E-ISSN 2655-7894 \\ Vol. 2, No. 1, Desember 2019, 24 - 33 \\ DOI: https://doi.org/10.31540/jpm.v2i1.636 \\ PENERBIT: LP4MK STKIP PGRI LUBUKLINGGAU}

straching dinamis dilakukan sebelum siswa melakukan permainan kecil bola basket.

Permainan kecil bola basket di sekolah dasar dapat diperkenalkan melalui pendidikan jasmani. Karena pendidikan jasmani merupakan proses pendidikan melalui penyediaan pengalaman belajar kepada peserta didik berupa aktivitas jasmani, bermaian, dan berolahraga yang direncanakan secara sistematis guna merangsang pertumbuhan dan perkembangan fisik, organik, keterampilan motorik, keterampilan berfikir, emosional, sosial dan moral. Dengan dilakukannya kegiatan sosialisasi streching dalam permainan kecilbola basket nantinya dapat peningkatan kemampuan siswa dalam permainan kecil bola basket yaitu line tiggy, Dribble Knockout, Team Dribble Relays (Speed Dribble \& Ball Handling), 4 Pass to Score, Bull in the ring.

Pelaksanaan kegiatan sosialisasi streching dalam permainan kecil bola basket ini juga merupakan kegaitan pelayanan kepada masyarakat yang dilaksanakan berasama mitra PERBASI Kabupaten Bangkalan. PERBASI Kabupaten Bangkalan sendiri yang merupakan organisasi olahraga di Kabupaten Bangkalan yang memang khusus melayani masyarakat dalam mengembangkan bakat dan minat cabang olahraga bola basket. melalui kerja sama antara akademisi olahraga dan pengurus cabang olahraga di daerah diharapkan pelayanan kepada masyarakat dalam bidang olahraga akan menghasilkan sebuah dampak yang positif bagi kemajuan olahraga bola basket di Bangkalan pada khususnya.

\section{SIMPULAN}

Salah satu tujuan pelaksanaan pendidikan jasmani, Olahraga dan Kesehatan di sekolah dasar adalah meningkatkan kemampuan dan keterampilan gerak dasar. Kemampuan gerak dasar dapat diterapkan dalam aneka permainan, olahraga, dan aktivitas jasmani yang dilakukan sehari-hari. Berdasarkan hasil dari kegiatan pengabdian masyarakat ini adalah adanya peningkatan pemahaman baru yang berorientasi kepada pemahaman tentang pelaksanaan pemanasan (streching) 


\section{JURNAL CEMERLANG: Pengabdian pada Masyarakat \\ P-ISSN 2654-4741 / E-ISSN 2655-7894 \\ Vol. 2, No. 1, Desember 2019, 24 - 33 \\ DOI: https://doi.org/10.31540/jpm.v2i1.636 \\ PENERBIT: LP4MK STKIP PGRI LUBUKLINGGAU}

dinamis pada siswa sekolah dasar sebelum melakukan olahraga, peningkatan kemampuan siswa dalam permainan kecil bola basket yaitu line tiggy, Dribble Knockout, Team Dribble Relays (Speed Dribble \& Ball Handling), 4 Pass to Score, Bull in the ring. Dalam pelaksanaan pengabdian tidak terlepas dari kekeliruan atau hal-hal tidak diprediksi maka penulis memberikan saran bahwa olahraga tradisonal harus diberikan pada sesi pemanasan dalam pembelajaran olahraga.

\section{DAFTAR PUSTAKA}

Adang Suherman. (2000). Revitalisasi Pengajaran Dalam Pendidikan Jasmani. Bandung: CV. Bintang Warli Artika.

Ahmadi, Nuril. (2007). Permainan Bola Basket. Surakarta: Era Intermedia.

Al-khalili. (2005). Mengembangkan kreativitas anak.Jakarta: Pustaka Al-Kautsar.

Ano, Anwar. 2010. Permainan Bola Basket. Fakultas keguruan dan Ilmu Pendidikan Universitas Haluoleo, Kendari.

Lutan, Rusli. (1997). Manusia dan Olahraga, Bandung: Penerbit ITB.

Mahendra (2009). Modul Asas dan Falsafah Pendidikan Jasmani. Bandung : Universitas Pendidikan Indonesia.

Sanoesi, dkk (2012). Teknik Dasar Permainan Bola Basket.Bse Penjasorkes.

Suherman. (2009). "Pengembangan Model Pembelajaran Outdoor Education Pendidikan Jasmani Berbasis Kompetensi di SD”, dalam jurnal ilmiah Universitas Pendidikan Indonesia, ed.254, hlm. 113-125.

Sumiharyono, Dedy. (2002). Keterampilan Basket. Yogyakarta: FIK UNY.

Sodikum, Imam. (1992). Olahraga Pilihan Bola Basket. Jakarta: Departemen Pendidikan dan Kebudayaan.

Tedjasaputra. (2001). Bermain, Mainan, dan Permainan. Jakarta: Grasindo.

Wissel, Hal. (2000). Bola Basket. Jakarta: PT Raja Grafindo Persada. 